\title{
Introduction \\ Socialities of Nature Beyond Utopia
}

Constanza Parra and Casey Walsh

\begin{abstract}
The articles in this section were written by social scientists from different parts of the world doing research on the complex relationship between human beings and the natural environment, and on the role of cultural ideals in shaping environmental history. The interdisciplinary character of the papers generates original insights about the socio-cultural dimensions of the environmental problematic, which have been neglected when compared with economic and political dimensions. This introduction reviews the contents of the proposed special symposium and situates the articles in relation to discussions about the social role of utopias, imagined and real.
\end{abstract}

\section{KEYWORDS}

environment, nature, nature-culture interactions, social innovation, utopia

\section{Alternative Socio-ecological Ideas and Practices in a Context of Crisis}

Optimism about human entanglements with the environment is hard to come by these days. Despite, and because of, great acceleration in scientific knowledge and technology over the last few hundred years, human-nature systems are in danger of collapse. Surface and subsoil water resources are drastically overtaxed and the ecosystems that they support are collapsing. The destruction of habitat is causing a wave of extinctions that rivals that of the dinosaurs. Overall, fossil fuel dependence and carbon emissions continue to intensify, but even if they were to plateau at today's levels, planetary warming would continue to increase over the next century. Measures by governments and powerful transnational actors to address complex socio-environmental questions are often weak, contradictory, and ineffective, and do not take into account the real impact of power relations within the economy and society. Clearly our relations with nature should be revisited from a broader socio-cultural perspective capable of inspiring and grounding alternative modes of governance and citizenship. 
The articles gathered in this special symposium of Nature + Culture discuss small efforts to address the current ecological crisis. The authors focus on alternative forms of human-environment interaction in an effort to rethink the foundations of the politics of nature, and gain some clarity about the possibilities of sustainability in a time of profound ecological and socio-economic turmoil. The authors address three main goals. First, they critically assess dominant political, economic, and socio-cultural models in order to understand the ways in which they have caused, enabled, or hindered environmental crises and conflicts at different governance scales. Second, they examine alternate traditions and visions of environmental stewardship and citizenship, and chronicle some of the diversity of creative and sustainable environmental values, worldviews, intelligences, and social practices that exist in various parts of the world. Third, they discuss how alternative cultures of nature have been marginalized as impractical, naïve, and utopian, but also how they have inspired more sustainable socio-ecological relations.

We use the word utopia to describe these alternative visions five centuries to the year after Thomas More's published his classic work with that title (1516). It is a word, we believe, that now more than ever captures the conundrums of modern human-environment relations and world-making actions we seek to elucidate. There is a long discussion in progressive thought about the power of ideas to solve deeply rooted social problems such as inequality or poverty, and often these visions of resolution are called utopian in a positive way. Just as often, however, the word utopian is used in a derisive way to dismiss such efforts as quixotic or unrealistic. In the case of those ideals that infuse totalitarian forms of power such as twentieth-century fascism and communism, the derision turns to horror about "dystopia." In the articles gathered here we search for utopia between these two endpoints, identifying, questioning, and transcending as much as possible these limitations.

It is in this sense that we hope to move "beyond" utopia. At the same time that we wish to engage with this long quest to realize human potential, we seek to move beyond the inevitable frustration of not achieving the perfection implied in the positive sense of the word. Similarly, we question the ideological dismissal of efforts at social change that are part and parcel of the negative connotations of the word utopia. Somewhere between the two poles we hope to reclaim utopian possibilities and recognize what Eric Olin Wright has called "real utopias" - existing efforts to form engagements and institutions 
based on social innovation and empowerment (Wright 2010). Faced with the urgent task of creating an environmentally, economically, and socially sustainable, just and cohesive society, we think that communities, practices, and ideas rejected as utopian and irrelevant, or dystopian and dangerous, are often laboratories of social innovation that inspire more friendly relationships among and between humans and nature (Parra 2013).

\section{Utopias and the Rebuilding of Nature-Culture Interactions}

The word utopia has been used in the modern age to evoke imaginary lands, regions, nations, and socio-political projects. Introduced to general discourse by Thomas More five hundred years ago, the term was brought into play to refer to an imagined place or state of perfection, a "no-place" (literal translation of the Greek) that contrasted with known places. In More's book, Utopia was described by a Portuguese mariner as a believable somewhere, uncharted yet entirely possible. This early modern version of utopia was inspired by the discovery of the American continent and by the remote transcontinental voyages this discovery encouraged, and utopias since have been conceived as an invitation to envision, explore, and construct a mental image of other possible worlds often located elsewhere, over the horizon, removed in time and/or space from the homeland. Utopia suggests that the world eclipsed by modernity, or still lying just beyond its grasp, is wholesome, fulfilling, and sustainable, and offers the chance that this world can be discovered intact, somewhere, or perhaps built anew.

Rather than understand utopias, as many have, to exist "nowhere" that is, not exist at all-we believe that utopian visions, hopes, and realities do exist everywhere, but that this existence is unknown, unrecognized, or ignored because of the obduracy of power and culture. To orient our effort to recover this alternate intellectual current in modernity, we build selectively on an ample tradition of discussing utopia. Frederick Engels, in his brief consideration of "Socialism, Utopian and Scientific" ([1880] 1970), argued that the visions promoted by Saint-Simon, Fourier, and Owen of harmonious communities were born around the year 1800 out of the disillusionment produced by the failure of European bourgeois revolutions to achieve the trumpeted promises of life, liberty, and happiness. Utopian ideas filled a vacuum created by the loss of hope that Reason would be sufficient to order the chaos of the emergent capitalist society. Engels admired their ef- 
forts, but he called these thinkers "utopian" because they failed to consider, scientifically, the world-historical conditions in which they lived, and hoped to push through revolutionary reforms on the basis of willpower.

A wave of left utopian thought emerged again in the 1920s and 1930s at another moment of crisis of hegemonic political narratives and ideals. From his cell in a fascist prison Antonio Gramsci (1971) pessimistically rejected "voluntarism" as a viable strategy, but nevertheless recognized the vital importance of optimism in building a radically different society. In the same historical moment Karl Mannheim offered a sociology of knowledge that shed light on the dynamics of both the conceptualization of alternate possible worlds, and the way those alternate visions are categorized as utopian. He proposed that "the representatives of a given order will label as utopian all conceptions of existence which from their point of view can in principle never be realized. According to this usage the contemporary connotation of the term 'utopian' is predominantly that of an idea which is in principle unrealizable" (Mannheim [1936] 1954: 176-177, italics original). In this view what is imagined and imaginable is related to class dynamics in the wide sense. "It is always the dominant group which is in full accord with the existing order that determines what is to be regarded as utopian," he continued, "while the ascendant group which is in conflict with things as they are is the one that determines what is regarded as ideological" (203). The relation between order and utopia is dialectical, an "epocal" historical analysis much like that used by Raymond Williams to theorize the relation between dominant and emergent aspects of culture (Williams 1977).

Culture may work in the way these theorists described at all moments in history, but these analyses are especially germane to moments of rupture such as the one we are living now. Today's world throws at us a double economic and ecological crisis etched in sharp relief against the millennial plateau: environmental degradation, jobless growth, debt, social inequality, poverty, hunger, and the utter failure to respond reasonably and concertedly to these problems. It is when the crises seem insurmountable that we feel the need to act in new ways; that there is nothing to lose from considering alternatives that are considered utopian. But what is to be done? The analysis from political economy is clear: these dual crises are the result of an incessant drive for profit and growth, through predation on commons, incorporation of new labor, and the rents of nature (Foster 2000; Harvey 2003; O'Connor 1997). As we grapple intellectually with the global 
juggernaut of capital accumulation, it seizes our imagination; too often we succumb to our own analyses of total power, making transformative action seem impossible (Gibson-Graham 2006).

In this context we reclaim the "utopian" as a domain of possibility, and seek out "real utopias" (Wright 2010) as models for practical action in the arena of social reproduction. Many of these actions are, upon closer examination, found to be embedded in the "diverse economies" (Gibson-Graham 2008) of people all over the world who creatively forge lives and livelihoods in precarious conditions in ways that do not simply reproduce exploitation and environmental destruction. These lifeways may not seem to be guided by radical principles, but rather appear "more immediate, more urgent, than addressing political economic equity or designing some new social or technological utopia" (Rajan and Duncan 2013: 70). We insist, however, in inquiring about the ideas and "hopes" (Bloch 1986) that shape and propel these adaptations, and the possibility that they can lead to positive transformation.

Utopian ideas and impulses guide efforts to make a living, but they also orient diverse ecologies and new human-environment relations (Veteto and Lockyer 2013). We capture that richness of ideas and practices with the term socialities of nature. On the one hand, this term considers the broad array of social relationships and institutional arrangements through which societies and communities are linked, formed, and constantly reshaped; on the other, it highlights the relational character of the nexus between human beings and nature. With the contemporary context of environmental crisis as a backdrop, these articles describe and analyze the content of socialities of nature in different socio-cultural and political contexts and at various spatial scales from the local to the global. Thus the papers collected here discuss local parks, people, and animals in Australia; popular participation in international negotiations on climate change; local mobilizations against pollution by corporations in South Africa; community-based environmental management in Tasmania; and multi-scalar environmental governance in the Chilean desert.

What all the contributions to this special symposium have in common is the attention that they give to community processes, and more precisely to the diversity of socio-ecological arrangements, negotiations, practices and cultures underpinning contemporary environmental problems and processes. Embedded in this array are concepts and attitudes that might be declared unreasonable or utopian, but which nevertheless take material form through practices and actions. In their combination, these "intelligences of nature" (Descola 2008) 
remind us that the concept of environmental governance must account for the entire multiplicity of social, political, and cultural dynamics and human agencies in interactive co-evolution with nature, which give shape to the socio-ecological plexus from which societies materialize. The nature-culture divide that emerged from the Enlightenment ignores this diversity of cosmologies, cultures, and people inhabiting this planet, and forms the ontological basis for denigrating them as backward, on the one hand, or utopian, on the other. Policies for nature and environmental protection will become effective only when we move beyond this dismissal and the plurality of nature intelligences, worldviews, and values are taken into consideration.

One essential piece of this socio-ecological plexus corresponds to what might be called alternative cultures of nature aimed at improving the quality of ongoing socio-ecological transformations, and bridging the divide between nature and culture. Within this reality, the word utopia is used in a positive and constructive sense as an invitation to imagine a multiplicity of virtual futures intersecting with alternatives that were not foreseen. It is also used as an invitation to explore how existing alternate socio-ecological traditions-perhaps informed by utopian visions or a politics of hope in a context of crisis-might lead to improvements in the governance of the commons, bridging lost connections between humans and nature through socially innovative collective action (Pilgrim and Pretty 2010). Have these utopias concretely contributed to sustainable nature-culture relations across the globe? And if so, how?

\section{The Articles}

The politics of the possible is paramount when it seems that you cannot get there from here; when the reasonable is recast as ridiculous, utopian. The works collected in this special issue are an exploration of the place and purpose of utopias lodged in "intelligences of nature." We seek to understand the ways the possible and the impossible are conjured as people take action to make the world better. Faced with the urgent task of creating an environmentally, economically, and socially just and sustainable society, communities and practices considered by many as utopian present themselves as laboratories of social innovation.

The articles evidence the socioeconomic and environmental problems that can be caused when the effective governance of ecol- 
ogies is assumed to derive from the governance model itself, usually figured as either the socialist state or the free market. Often the management of the economy and environment is determined from the top down by a small group of people in a narrow and quite undemocratic fashion. Especially in countries with fragile environmental regulation, recent initiatives to protect the environment easily become the object of political struggle, with a real risk of diminishing their sustainability. Alternate, utopian modes of governance combine new scientific approaches (transdisciplinarity, grounded theory, living science) with new forms of democratic citizenship (sustainable development through social innovation, bottom-up policy making), which find active applications in community learning practice, shared envisioning of ideal futures, and post-normal scientific activism. This volume addresses these ignored, unseen, and sometimes novel intimations of socio-ecological futures.

Following this introduction, Constanza Parra and Frank Moulaert discuss the contemporary concern in ecological and social science literature to restore the unity between "nature" and "culture" as a way to improve the governance of social-ecological systems. Based on indepth research in San Pedro de Atacama, Chile, the authors reflect on the extent to which historical learning processes might be relevant for encouraging certain modes of governance that would serve the social-ecological sustainability of fragile ecosystems. They see recently empowered indigenous people, culture, and institutions in this region as holding utopian potential but also problems for the recovery/reconstruction of sustainable human-nature relations.

Donna Houston, Diana McCallum, Wendy Steele, and Jason Byrne explore the ways that residents of Australian cities have created alternative understandings of, and participations in, climate change and politics. They deploy a reading of Isabelle Stenger's concept of "cosmopolitics" that confronts urban planning with the urgent need to build connections between the multiplicity of human and non-human experiences. These authors push back against the totalizing conceits of planners and climate change researchers, presenting evidence from a heterotopia of particular initiatives of everyday people: to witness the way fruit bats and other species deal with climate change in a botanical garden; to build local community in a suburbia through the creation of a community assets inventory and gardens; to change the food system through gleaning and guerrilla gardening; and so on.

Similar political dynamics are examined by Zoe Bray and Christian Thauer in their study of the political processes associated with 
"corporate social responsibility" in South Africa. The promise of globalization, they argue, is too often portrayed by elites as a solution for all that ails. The reality seen by social research, however, is that it promotes quite varied and often negative socio-economic effects for most people, especially in the developing world. Using data gathered in ethnographic fieldwork, the authors show how local social and political movements engage with the total promise of globalization through local and partial efforts to force companies to engage in socially and environmentally responsible ways. By reworking neoliberal discourses and redeploying them from a different social locus, these social movements both reproduce the utopian hope of globalization discourse and relocate it to the reality of everyday life.

Climate change threatens to cause monumental problems on a global scale, affecting disproportionately the poorest and least powerful of the world's inhabitants. Richard Widick and John Foran trace the importance of utopian thought and aspiration in the climate justice movement. They explore the cultural roots of utopian thought in modern society, and present an ethnographic discussion of how social action and activist identity is called into being in the "auto-poesis of collective action." This profoundly dialectical approach to understanding the cultural field of power of the Climate Summits (Conference of the Parties [COP]), as well as the emergence and tactics of the activists mobilizing around these COP meetings, provides a sophisticated material and cultural theorization for the coming into being of utopia.

Local democratic social movements are a central topic of research in all the articles collected here, and through a reflection on his own work, activist and scholar Phil Tattersall provides an important discussion of how intellectuals reshape science through their participatory action. Tattersall discusses various ideas about research/action that have shaped his involvement in local environmental movements in Tasmania. His article on "community auditing," a political process that he designed and implemented, shows how social movements and intellectuals who participate in them inevitably move beyond both utopian idealism, as well as the critiques that their ideas and actions are utopian, in probing the horizon of the possible.

Taken together these articles think through the crisis of the present, and confront in a hopeful and realistic manner the problem that in order to expand the frontiers of the politics of the possible, utopian thought must be both criticized and upheld at the same time. The authors aim to move "beyond" the conservative dismissal of utopian thinking as pie in the sky, but also "beyond" those abstract and exotic 
models that undergird inequality and oppression. They show that utopias emerge in particular historical and social contexts, and that these positions must always be considered in efforts to identify and build real utopias that offer a possibility of resolving in a constructive manner the economic and environmental problems we face today.

\section{Acknowledgments}

The editors would like to thank all those who supported this project: The Regional Integration and Social Cohesion Consortium (RISC), the Interdisciplinary Humanities Center of the University of California at Santa Barbara, and the Planning and Development Unit, KU Leuven, Belgium. We particularly thank Lindsay Vogt for her editorial assistance.

Dr. Constanza Parra is assistant professor at the Division of Geography and Tourism, Department of Earth and Environmental Sciences, at the University of Leuven, Belgium. She is an environmental social scientist with interdisciplinary interests in the ways societies relate to the natural environment and deal with contemporary sustainability challenges. Her research focuses on social sustainability, social innovation, nature-culture nexus in socioecological systems, and multilevel governance of protected areas. Address: KU Leuven, University of Leuven, Division of Geography and Tourism, Department of Earth and Environmental Sciences, Celestijnenlaan 200e, 3001 Heverlee, Belgium. E-mail: constanza.parra@ees.kuleuven.be.

Dr. Casey Walsh is associate professor of anthropology at the University of California, Santa Barbara. His interests include political economy, political ecology, and the history of anthropology, and his work centers on Mexico and the Southwestern United States. Past research focused on the history of irrigated cotton production in the Mexico-US Borderlands (Building the Borderlands, Texas A\&M University Press, 2008). He is currently writing a book on the social use of mineral springs and hot springs in Mexico, and beginning a project on groundwater management in California. Address: University of California Santa Barbara, Department of Anthropology, Santa Barbara, CA. 93106-3210, USA. E-mail: walsh@anth.ucsb.edu.

\section{References}

Bloch, Ernst. 1986. The Principle of Hope. 3 vols. Cambridge, MA: MIT Press.

Descola, Philippe. 2008. "A qui appartient la nature?" La vie des idées.fr. www.lavie desidees.fr/IMG/pdf/20080118_descola.pdf (accessed 24 June 2016). 
Engels, Friedrich. [1880] 1970. Marx/Engels Selected Works. Vol. 3, pp. 95-151. Progress Publishers. www.marxists.org/archive/marx/works/1880/soc-utop/index.htm (accessed 24 June 2016).

Foster, John Bellamy. 2000. Marx's Ecology: Materialism and Nature. New York: Monthly Review Press.

Gibson-Graham, J. K. 2006. The End of Capitalism (As We Knew It): A Feminist Critique of Political Economy. Minneapolis: University of Minnesota Press.

Gibson-Graham, J. K. 2008. "Diverse Economies: Performative Practices for 'Other Worlds."' Progress in Human Geography 32(5): 613-632.

Gramsci, Antonio. 1971. Selections from the Prison Notebooks of Antonio Gramsci. New York: International Publishers.

Harvey, David. 2003. The New Imperialism. Oxford: Oxford University Press.

Mannheim, Karl. [1936] 1954. Ideology and Utopia: An Introduction to the Sociology of Knowledge. London: Routledge \& Kegan Paul.

More, Thomas. [1516] 1997. Utopia. Mineola, NY: Dover Thrift Editions.

O'Connor, James. 1997. Natural Causes: Essays in Ecological Marxism. New York: Guilford Press.

Parra, Constanza. 2013. "Social Sustainability: A Competitive Concept for Social Innovation?" In International Handbook on Social Innovation: Collective Action, Social Learning and Transdisciplinary Research, ed. Frank Moulaert, Diana McCallum, Abid Mehmood, and Abdel-Illah Hamdouch, pp. 142-154. Cheltenham, UK: Elgar.

Pilgrim, Sarah, and Jules Pretty, eds. 2010. Nature and Culture: Rebuilding Lost Connections. Washington, DC: Earthscan.

Rajan, S. Ravi, and Colin Duncan. 2013. "Ecologies of Hope: Environment, Technology and Habitation: Case Studies from the Intervenient Middle." Journal of Political Ecology 20: 70-79.

Veteto, James, and Joshua Lockyer. 2013. Environmental Anthropology Engaging Utopia: Bioregionalism, Permaculture, and Ecovillages. New York: Berghahn Books.

Williams, Raymond. 1977. Marxism and Literature. Oxford: Oxford University Press. Wright, Eric Olin. 2010. Envisioning Real Utopias. London: Verso. 